\title{
FURTHER INVESTIGATIONS ON PITUITARY GLAND IMPLANTATIONS IN RHEUMATOID ARTHRITIS
}

\author{
BY \\ GUNNAR EDSTRÖM and STIG THUNE \\ From the Arthritis Clinic and Department of the University Hospital, Lund, Sweden
}

Experiences in the Arthritis Department of the University Hospital, Lund, of pituitary gland implantations in cases of rheumatoid arthritis have been previously reported in this journal (Edström, 1950a). Now that another hundred cases have been treated in the department, the period of observation since the operations has become longer, and the operative technique somewhat modified, and it is possible to present a further report.

\section{Technique}

(1) The following technique was employed in all the cases reported below:

Fresh anterior lobes of pituitary glands from calves and pigs were used. Immediately after the animals were killed the heads were taken to the hospital. The anterior lobes were excised aseptically in a preparation room adjacent to the operation room. The heads were fixed in a special position and flayed, the skull was sawn off and the brain taken out. Using sterile gloves, the surgeon exposed and excised the pituitary gland with the adjoining pedicle, including as much as possible up towards the tuber cinereum. The posterior lobe was then cut off. The hypophyses were usually divided into two parts.

Under local anaesthesia a deep incision, 1.5 to $2 \mathrm{~cm}$. long, was made in the skin, down into the gluteal muscles, or laterally in the thigh muscles. A $9 \mathrm{~cm}$. long-nose speculum was introduced and two or three of the split hypophyses were implanted. The skin was then sutured.

The time that elapsed between the killing of the animals and the re-introduction of the anterior lobes of the pituitary glands into living tissue was approximately 30 minutes, and never exceeded 45 minutes.

(2) We also tried another method whereby the lobes were reduced to a pulp and injected by means of a large-aperture needle. This procedure, however, is no good if a foreign-body reaction occurs. There is then a considerable amount of detritus, which requires a considerable time to be eliminated, even if the reaction is mild and there is no growth of pathogenic bacteria. When the fragments are introduced whole they are more easily expelled, and the reaction is inconsiderable and only lasts a day or two, particularly when it is alleviated by means of some antihistamin preparation.

(3) In the last two months we have tried a new technique, partly in accordance with that used in Vienna by Fellinger (1950a, b), who introduced a modification by freezing the hypophyses after slaughter until they are used for implantation.

In the slaughter-house in Kävlinge, which supplies us with hypophyses, the glands are taken from practically every pig for delivery to pharmaceutical factories for the preparation of ACTH. The slaughtering is carried out by the conveyor-belt system, which deals with approximately 150 animals per hour. Five minutes later, when the bodies 
are scalded and the viscera removed, they reach a man with a revolver-shaped apparatus provided with a rotating sawing barrel. With this instrument he removes from the ventral side of the skull a cylindrical mass with the hypophysis in the middle. Opposite him stands a technician who excises the hypophyses with a pincette and places them in a small container surrounded by ice. When the hypophyses are destined for our laboratory, the technician using a sterile pincette selects those that have not been contaminated by the rotating cylinder. These are then collected in an aseptic. Petri dish, which is immediately placed between two packings of solid $\mathrm{CO}_{2}$ in a specially-constructed thermos flask (the temperature being below $-20^{\circ} \mathrm{C}$.). The flask is then taken to the hospital where it is kept in a refrigerator until the operations are to be performed. When the hypophyses are taken out again they are like hard-frozen marbles, and are therefore allowed to thaw for 6 or $7 \mathrm{~min}$. in a 0.1 per cent. septin (quaternare ammonium compound) solution before being implanted in the manner previously described. By this method four to seven hypophyses are usually used in one operation.

According to our calculations based on observations of the practical application of this freezing method as a step in the mechanized system in the slaughter-house, about 15 minutes elapse between the killing of the animal and the placing of the hypophyses in the thermos flask. In our experience an instantaneous freezing like the one mentioned by Fellinger $(1950 \mathrm{a}, \mathrm{b})$ cannot be realized in a large slaughter-house, and we believe it to be practically impossible even in a small one. Judging from tests made in the clinic, a combined freezing and thawing time of 25 to $30 \mathrm{~min}$. seems to be permissible without impairing the biological effect.

\section{Clinical and Biochemical Effect}

Clinical effect, when present, almost always occurred during the first 2 days following the first implantation, and sometimes after later implantations. Objectively, reduced peri-oedema around the affected joints, improved mobility, and a slight euphoria with increased mental capacity and activity, were noted. Subjectively, the patients reported considerably reduced tenderness on moving,

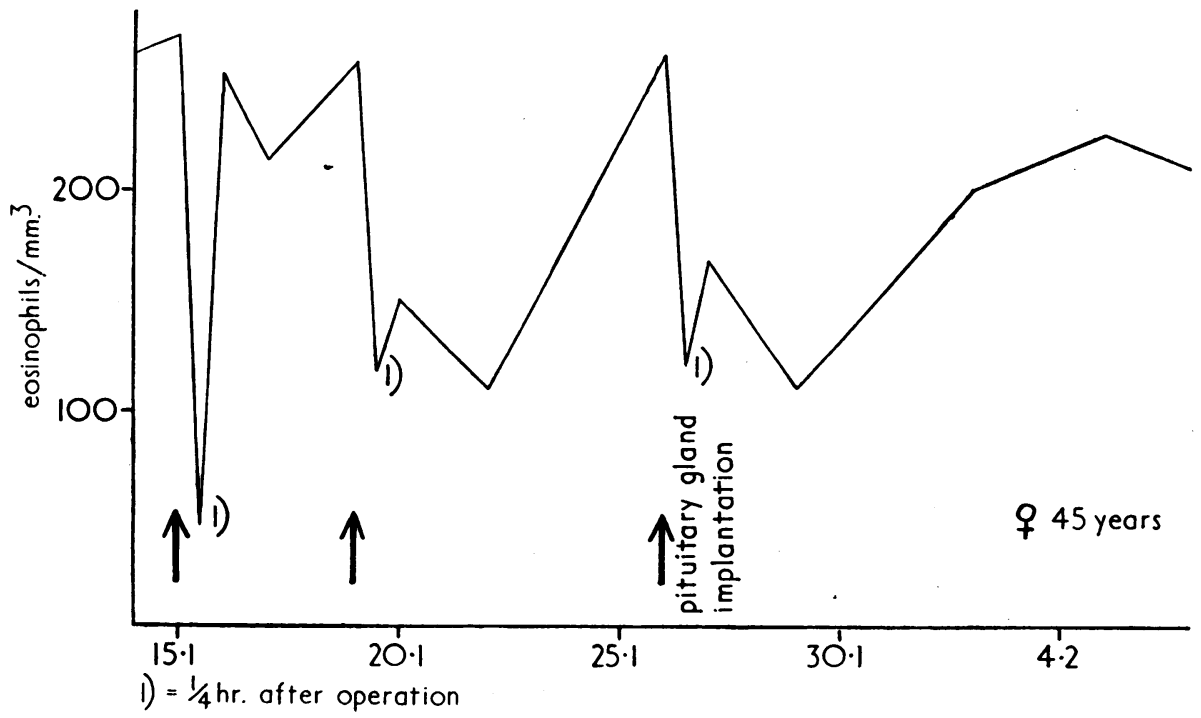

FIG. 1.-Fall in eosinophil leukocytes in circulating blood between Jan. 15 and Feb. 6. 
reduced stiffness in both joints and muscles, improved movement, less feeling of being ill-a similar effect to that obtained after the injection of ACTH. The following biochemical changes were noted:

(1) marked fall in the number of eosinophil leukocytes in the circulating blood (usually by much more than 50 per cent.) was seen after 4 hours and lasted for 2 or 3 days (Fig. 1);

(2) approximately twofold increase in 17-ketosteroids in the urine occurred for a 24-hour period (Fig. 2);

(3) reduction of the lymphocytes and an increase in the polynuclear leucocytes during the first 24 hours;

(4) increased excretion of uric acid in the urine during the first 24 hours (Fig. 3);

(5) lowered erythrocyte sedimentation rate, which develops more slowly and does not become pronounced until two weeks later.

There was no certain effect on the electrolytes in the serum and no change in weight.

As will be seen, the effects are, in many respects, similar to those obtained with injections of ACTH, although not so marked or pronounced, particularly from a biochemical point of view. They are, instead, in most cases of longer duration clinically. In order to give a more extensive view of the clinical effect all the cases in which the time of observation following the implantations was at least 9 months, are tabulated below.

No clinically demonstrable effect was obtained in about 25 per cent. of cases. In another 25 per cent. relapses occurred after a period of 10 to 15 weeks free from symptoms of any existing process. Six of these eleven cases were re-admitted to

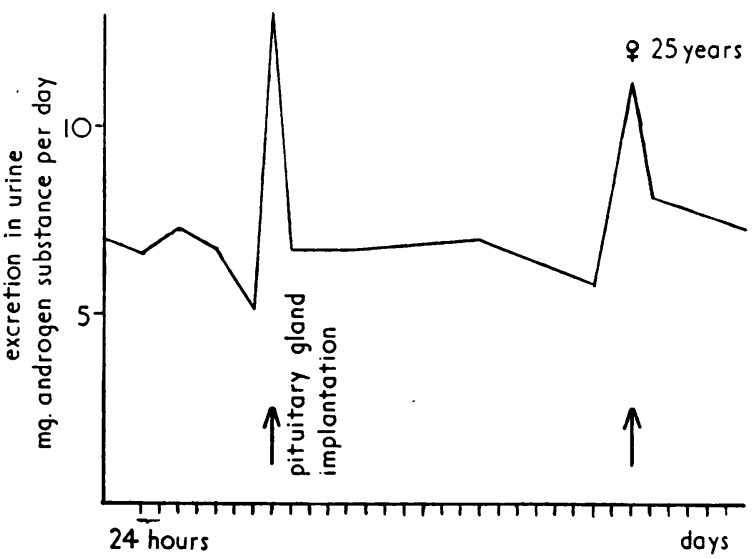

FIG. 2.-Increase in 17-ketosteroid excretion in urine.

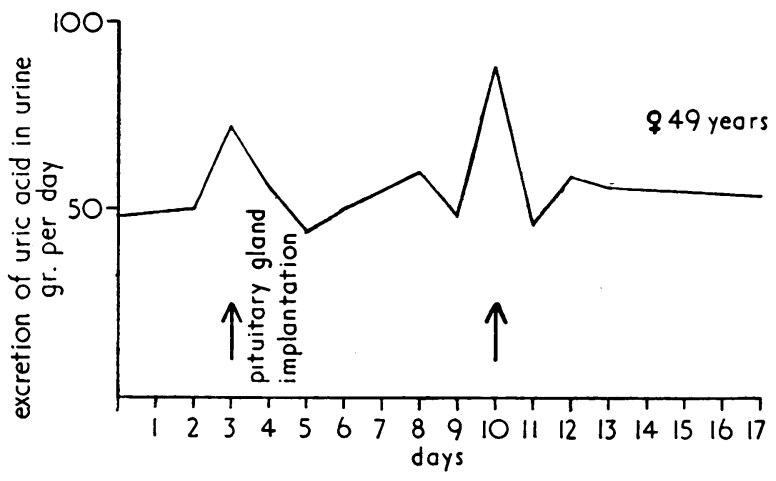

FIG. 3.-Increase in uric acid excretion in urine. the hospital and received new implantations (four patients are at present symptomfree, and the other two improved temporarily, but had another relapse). Out of 
51 cases, 22 showed clinical effects which have persisted for 9 months, and twenty of these have been entirely free from symptoms of any existing process (Table I).

TABLE I

CLINICAL STATE IN DECEMBER, 1950, OF 51 RHEUMATOID ARTHRITIS CASES IN WHICH PITUITARY GLAND IMPLANTATIONS WERE DONE BETWEEN SEPTEMBER, 1949 AND MARCH, 1950 (IN CHRONOLOGICAL ORDER)

\begin{tabular}{|c|c|c|c|c|c|}
\hline Clinical Effect & Group I & Group II & Group III & Total & Percentage \\
\hline 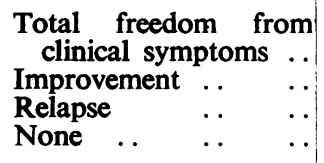 & $\begin{array}{l}4 \\
2 \\
2 \\
2\end{array}$ & $\begin{array}{r}10 \\
4 \\
2 \\
5\end{array}(4)$ & $\begin{array}{l}8 \\
3 \\
3 \\
6\end{array}$ & $\begin{array}{c}22 \\
9 \\
7(11) \\
13\end{array}$ & $\begin{array}{l}43 \\
17 \\
14(22) \\
26\end{array}$ \\
\hline Total Cases & 10 & 21 & 20 & 51 & 100 \\
\hline
\end{tabular}

Spontaneous relapses are quite common during the course of rheumatoid arthritis. This makes it difficult to evaluate our various kinds of treatment. The cases in question were on the whole of average severity and, with two exceptions, of at least 5 months' duration. Some of them were very malignant and of long duration. When considering these facts the result must be described as satisfactory, at least according to present standards.

The influence of the patients' age is seen in Table II. As a rule the older the patient, the poorer the result. The similarity to the animal experiments of Silberberg and Silberberg $(1939,1940,1949)$ is obvious. These investigators observed proliferation of the articular cartilages after implantation of pituitary glands in rats. In older animals the effect was much less common: instead degeneration and reactionary changes often occurred.

TABLE II

SAME MATERIAL AS TABLE I, BY AGE GROUPS*

\begin{tabular}{|c|c|c|c|c|c|c|c|}
\hline \multirow{2}{*}{\multicolumn{4}{|c|}{ Clinical Effect }} & \multicolumn{2}{|c|}{ Under 40 Years of Age } & \multicolumn{2}{|c|}{40 Years Old or More } \\
\hline & & & & \multirow{2}{*}{$\begin{array}{c}\text { Cases } \\
16 \\
7 \\
4 \\
7\end{array}$} & \multirow{2}{*}{$\begin{array}{c}\text { Per cent. } \\
\frac{47}{-} \\
\frac{21}{21}\end{array}$} & \multirow{2}{*}{$\begin{array}{c}\text { Cases } \\
6 \\
2 \\
3 \\
6\end{array}$} & \multirow{2}{*}{$\frac{\text { Per cent. }}{\frac{35}{-}}$} \\
\hline $\begin{array}{l}\text { Total freedom } \\
\text { Improvement } \\
\text { Relapse } . . \\
\text { None } \quad . .\end{array}$ & $\begin{array}{l}\text { om c } \\
\ldots \\
\cdots \\
\cdots\end{array}$ & $\begin{array}{c}\text { nical } \\
\ldots \\
\ldots \\
\ldots\end{array}$ & $\begin{array}{l}\text { mptoms . } \\
\ldots \\
\cdots \\
\cdots\end{array}$ & & & & \\
\hline Total Cases & .. & .. & .. & 34 & & 17 & \\
\hline
\end{tabular}

* One case 9 years old. three 11 to 18 years, fifteen 20 to 29 years, fifteen 30 to 39 years, sixteen 40 to 49 years, and one 50 years.

Another factor influencing the result is the length of time that the patient has suffered from the disease (Table III, opposite).

\section{Discussion}

It is improbable that the effect obtained in these implantations is other than a transient hormonal shock from the implanted gland, a stimulation of the adrenal cortex, judging from the biochemical reactions of hardly more than 24-hours' 
TABLE III

SAME MATERIAL AS IN TABLES I AND II, BY DURATIO MORBIS AT TIME OF FIRST IMPLANTATION

\begin{tabular}{|c|c|c|c|c|c|c|}
\hline \multirow{3}{*}{ Clinical Effect } & & & \multicolumn{2}{|c|}{ Duratio Morbis* } & & \\
\hline & \multicolumn{2}{|c|}{ Less than 1 Year } & \multicolumn{2}{|c|}{ From 1 to 2 Years } & \multicolumn{2}{|c|}{2 Years or More } \\
\hline & Cases & Per cent. & Cases & Per cent. & Cases & Per cent. \\
\hline $\begin{array}{lll}\text { Total freedom } & \text { from } \\
\text { clinical symptoms } & . . \\
\text { Improvement } & . . & . \\
\text { Relapse } & . & . \\
\text { None } . . & . & .\end{array}$ & $\begin{array}{r}10 \\
1 \\
3 \\
3\end{array}(5)$ & 18 & $\begin{array}{l}4 \\
2 \\
2 \\
3\end{array}$ & 27 & $\begin{array}{l}8 \\
6 \\
2 \\
7\end{array}$ & 35 \\
\hline Total Cases & 17 & & 11 & & 23 & \\
\hline
\end{tabular}

* Duratio morbis in one case 2 months, in one 4 months, in three 5 months (one of these showed no clinical effect), in one 6 months, and in eleven 7 to 11 months.

duration. That it is a prolonged effect of transplantation type, as originally suggested, is quite out of the question; Westman and Jacobsohn $(1940,1942)$, for example, showed that the implanted anterior lobes of the pituitary glands are necrosed and absorbed rather quickly.

Stimulation of the adrenal cortex can be brought about in different ways. A depression of the eosinophil leukocytes in the circulating blood has been observed after the administration of anaesthesia to a patient. In order to exclude the possibility that the shock of operation itself causes the reactions observed, control experiments have been carried out and pieces of calf brain without any hypophysis have been implanted with the same operative technique. In the control experiments none of the biochemical reactions related above were observed, nor was there any effect on the patient's clinical status.

The stimulation of the adrenal cortex caused by the implanted pituitary glands is not quite parallel to that obtained through injection of ACTH. The effect sets in more slowly and lasts longer. The ACTH-molecule is very small and injected ACTH is excreted very rapidly, principally in the urine. Judging from animal experiments about half the amount is probably excreted within 5 minutes. The optimum stimulation of normal adrenal function is achieved by the injection of 7 to $8 \mathrm{mg}$. ACTH. The effect of the biologically active hormone produced by the implantate occurs more slowly and continuously during a certain time, probably about 24 hours. This method of administering the hormone is probably better and more effective from a biological point of view. It is not certain whether the effect is caused by the ACTH or by another similar but biologically more effective substance. The amount of ACTH obtained from the same amount of pig or calf hypophyses has increased almost tenfold in the last 2 years because of improved methods of extraction. Everything indicates that it will increase still further and that at present we are ignorant of how much adrenocorticostimulating substance is contained in one hypophysis. Most probably, ACTH is not the only stimulating substance and these compounds may differ in chemical 
form. This would explain the considerable adrenocortico-stimulating effect of a few implanted anterior lobes of hypophyses, although our present methods have disclosed only a small amount of ACTH (viz. 1-3 mg.). The effect seems to be increased when the pedicle towards the tuber cinereum is also included. In this connection one case is of particular interest.

Case 1. A 45-year-old male was treated in September and October, 1949, without effect with three implantations of calf pituitary glands, consisting of two anterior lobes each, at one-week intervals. Then small doses of testosterone were given, likewise without effect. When the dosage was increased to $100 \mathrm{mg}$. testosterone injected intramuscularly supplemented with $500 \mathrm{mg}$. ascorbic acid given intravenously twice daily, a certain clinical effect was obtained, which, however, passed off as soon as the dosage was reduced. In October, 1950, this patient was treated with ACTH; on the first day he received $5 \mathrm{mg}$. eight times, on the second day $5 \mathrm{mg}$. six times, on the third and fourth days $5 \mathrm{mg}$. five times. There was a marked clinical and biochemical effect. When the dose was reduced to $5 \mathrm{mg}$. three times on the fifth day the clinical symptoms reappeared on the sixth day, and the number of eosinophil leukocytes, which had fallen markedly, began to rise again. Clinical effect was not obtained again until a few days later when the ACTH dose was increased to $5 \mathrm{mg}$. five times a day. It seems as if comparatively high doses of steroid hormones were necessary in this case to obtain clinical effect, and that implantation in such cases cannot produce a sufficiently powerful hormonal shock.

During the year when these implantations were carried out, another ten cases of rheumatoid arthritis were treated with injections of cortisone and ACTH. In two cases, one treated with cortisone and one with $\mathrm{ACTH}$, a prolonged remission of the clinical symptoms was obtained, a result similar to that obtained in twenty of the implantation cases mentioned above.

Case 2. A 12-year-old boy with a particularly malignant rheumatoid arthritis and considerable arthritic exudations. The erythrocyte sedimentation rate was approximately $100 \mathrm{~mm}$. per hour and the temperature subfebrile. This condition had lasted for about 6 months, and neither salicylic acid, large doses of penicillin, sulphonamides, blood-transfusions, or desoxycorticosterone acetate had had any effect. Treatment with cortisone was then initiated: $100 \mathrm{mg}$. twice daily for 2 days, followed by $50 \mathrm{mg}$. twice daily for 6 days, $50 \mathrm{mg}$. once a day for 4 days, and $25 \mathrm{mg}$. once a day for 2 days. The effect was dramatic. The erythrocyte sedimentation rate fell to $6 \mathrm{~mm}$. per hour and the clinical symptoms disappeared altogether. This condition has now lasted for more than 8 months; the patient has still completely normal joints and there are no symptoms from the heart or other organs.

Case 3. A 4-year-old boy, who had suffered from an extremely malignant rheumatoid arthritis with marked changes in the joints, high erythrocyte sedimentation rate, and subfebrile temperature for the past year, and had not responded to any therapy whatsoever (Edström, 1949). In September, 1949, he received ACTH for a little more than 2 weeks with an average dose of $15 \mathrm{mg}$. three times a day. During the treatment he was seen to move more easily and he complained less of pain. However, no reduction in the exudation or peri-oedema of the joints was observed, nor was there any change in temperature which remained around $38^{\circ} \mathrm{C}$., sedimentation rate, or pulse. About 10 days after the completion of the injections, however, the picture changed. For 3 days the temperature sank gradually to normal values $\left(36 \cdot 7^{\circ}-37 \cdot 1^{\circ} \mathrm{C}\right.$.). At the same time the exudation and peri-oedema around the affected joints disappeared. This was particularly noticeable on the hands and feet. The patient began to move like a normal child. The effect on the sedimentation rate came more slowly and was only slight during the first weeks.

About 4 weeks after being discharged from the hospital the patient fell ill at home 
with acute tonsillitis. He had a recurrence of polyarthritis symptoms which, however, lasted only 2 weeks. After that the erythrocyte sedimentation rate continued to fall, the patient increased in weight and improved more and more. In May and December, 1950 , he had a catarrhal infection, but no recurrence of the rheumatoid syndrome.

Though not completely free from symptoms, he is afebrile and is playing and running about, more or less like other children. The wrists and insteps are somewhat thickened, but there is no tenderness. Both the boy and his parents are satisfied with this compara-. tively quiet and agreeable condition, which has now lasted for more than one year.

Similar delayed results after injections of ACTH were observed by Waldenström (1950). In two cases of the pituitary gland implantations reported here the clinical effect did not occur until 2 weeks after the implantation.

Westman (1949) reported the delayed results of a series of 246 cases of endocrine disturbance in which implantation of the anterior lobes of pituitary glands had been carried out, all of which had been followed for more than one year. In a fairly large number a persistent effect was obtained. Similar results have been described by Nystrand (1947) and Kylin (1937, 1943). There are also recent reports of implantation being attempted in other conditions. At the hospital in Lund a few cases of disseminated sclerosis have been treated and the effect lasted for about three months. Svartz (1949) described a case of lupus erythematosus from the Karolinska Sjukhuset in Stockholm, where implantation was tried with satisfactory results. At a congress held at Bad Gastein, Austria, in September, 1950, Fellinger, of Vienna, gave an account of more than 1,000 cases, predominantly of rheumatoid arthritis, in which he had made pituitary gland implantations with much the same results as ours. In his series, however, relapses occurred more commonly and more rapidly than in our material. One of us (G.E.) talked with a colleague who had been treated by Fellinger for severe rheumatoid arthritis of many years duration, and who reported that he had not felt so well in many years as during the 3 months immediately following the implantations. He said that later the symptoms reappeared, but he still considered himself much improved after the implantations. We have received numerous reports by letter from clinics in different countries, and, on the whole, the experiences described are similar to ours. In older patients improvement is rare, and relapses are frequent, although they do not usually occur until 2 to 4 months after treatment.

The present findings should stimulate further research. A new method should be sought by which a hormone-depot, or prolonged effect of ACTH or of extract from the anterior lobes of the pituitary gland, can be obtained.

\section{Summary}

Implantations of anterior lobes of the pituitary gland of pigs or calves have been made in about 100 cases of rheumatoid arthritis in the Arthritis Department of Lund Hospital. Fresh pituitary glands were used, as it is important that the procedure be carried out rapidly. Lately, attempts have been made to preserve the fresh hypophyses by deep-freezing.

Of the 100 cases, 51 were observed for 9 months after treatment. Approximately half (27 cases) of this group are still without clinical symptoms or considerably 
improved, twenty having been totally free from clinical symptoms; eleven have had relapses, generally after about 3 months, and thirteen showed no clinical effect. As a rule, the older the patient, the poorer the result.

The clinical effect, when it occurred, usually manifested itself immediately after the operation. The increased excretion of 17-ketosteroids and uric acid usually disappeared within 24 hours; the reduction of the number of eosinophil leukocytes in the circulating blood, which was marked after 4 hours, sometimes lasted 2 or 3 days. Other biochemical reactions were uncertain and less marked.

The results, though not remarkable, seem to be of scientific interest. A method must be sought whereby the effect of ACTH can be prolonged.

\section{REFERENCES}

Edström, G. (1950a). Annals of the Rheumatic Diseases, 9, 22.

(1950b). Nord. Med., 43, 263.

and Thune, S. (1951). Svenska Läkartidn., 48, 456.

Fellinger, K. (1950a). Wien. klin. Wschr., 62, 9.

(1950b). Lecture given on 11.9 .50 at Bad Gastein to the Austrian League against Rheumatism.

Kylin, E. (1937). Acta med. scand., 91, 428.

- (1943). Svenska Läkartidn., 40, 574, 1612.

Nystrand, F. (1947). Nord. Med., 35, 1481.

Silberberg, M., and Silberberg, R. (1939). Arch. Path., 28, 340.

- - (1940). Anat. Rec., 78, 549.

- (1949). Annals of the Rheumatic Diseases, 8, 307.

Svartz, N. (1949). Lecture to Svenska Fören. f. inv. Med., Stockholm.

Waldenström, H. (1950). Lecture to Malmö Läk, Fören, Malmö.

Westman, A. (1949). Nord. Med., 41, 1019.

-, and Jacobsohn, D. (1940). Acta path. microbiol. scand., 17, 328.

$\longrightarrow$ - (1942). Ibid., 19, 34.

\section{La Greffe de la Glande Pituitaire dans l'Arthrite Rhumatismale}

\section{RÉsumé}

Des greffes de lobe antérieur de l'hypophyse de porc et de veau furent effectuées dans à peu près 100 cas d'arthrite rhumatismale au Départmente d'Arthrite de l'Hôpital de Lund. Des hypophyses frais furent utilisés, car il est important que l'opération soit exécutée rapidement. Récemment on avait essayé de conserver la fraicheur des glandes en les congélant.

Sur ces 100 cas, 51 durent suivis pendant 9 mois après le traitement. On nota une amélioration considérable chez la moitié d'entre eux (27), avec absence totale de symptômes cliniques chez 20; il y eut des rechutes chez 11 , généralement 3 moisenviron après les greffes; l'effet clinique fut nul chez 13 .

L'effet clinique, quand il se produisait, se manifestait généralement immédiatement après l'opération. L'excrétion augmentée des 17-cétostéroïdes et de l'acide urique devenait normale généralement au bout de 24 heures; la diminution du taux des éosinophiles, prononcée au bout de 4 heures, persistait quelquefois pendant un ou deux jours. D'autres réactions biochimiques étaient inconstantes et peu prononcées.

\section{El Injerto de Glándula Pituitaria en Casos de Artritis Reumatoide}

\section{RESUMEN}

Injertos de lóbulos anteriores de glándulas pituitarias de cerdo o ternero han sido realizados, en el Departamento de Artritis del Hospital de Lund, en cerca de 100 casos de artritis reumatoide. Las glándulas pituitarias fueron usadas frescas, siendo importante que la operación se realice rapidamente. Ultimamente se han hecho tentativas para preservar frescas las hipófisis, mediante congelación. De los cien casos, 51 fueron observados por nueve meses después del tratamiento. Aproximadamente la mitad de este grupo (27), se encuentran todavía sin síntomas clínicos o considerablemente mejorados-20, enteramente libres de síntomas clínicos. 11 casos han tenido recaídas, generalemente con tres meses de posterioridad a los injertos, y (13) no demostraron efectos clínicos.

Los efectos clínicos, cuando ocurrieron, se manifestaron usualmente inmediatamente después de la operación. El incremento de la secreción del ácido úrico y de los 17-cetoesteroides generalemente desapareció dentro de las primeras 24 horas; la diminución de la cifra de los eosinófilos en la corriente sanguínea, notable después de 4 horas, algunas veces duró uno o dos días. Otras reacciones bíoquímicas fueron inciertas y poco pronunciadas. 